Т. А. Доронина

канд. пед. наук, доцент

\title{
«РУССКИЕ САПФО॥ МИРРА ЛОХВИЦКАЯ И СОФИЯ ПАРНОК - ДВЕ ПОПЫТКИ ЛИРИЧЕСКОЙ ИСПОВЕДИ
}

Статтю присвячено питанням гендерної проблематики літературознавства, в рамках якої розглядається лірична творчість російських письменниць початку ХХ століття.

«Серебряный век» русской поэзии - это название стало устойчивым для обозначения русской поэзии конца XIX - начала XX века. Оно было дано по аналогии с «золотым веком» (так называли начало XIX века, пушкинское время). О русской поэзии «серебряного века» существует обширная литература - о ней много писали и отечественные, и зарубежные исследователи, в т. ч. такие крупные ученые, как В. М. Жирмунский, В. Орлов, Л. К. Долгополов, М. Л. Гаспаров, Р. Д. Тименчик, Н. А. Богомолов и многие другие.

Конец XIX - начало XX вв. в России - это время перемен, неизвестности и мрачных предзнаменований, это время разочарования и ощущения приближения гибели существующего общественно-политического строя. Все это не могло не коснуться и русской поэзии. Исторические события данного периода предопределили возникновение в литературе символизма, акмеизма и футуризма. Развитие различных тенденций вело к возникновению между ними литературной борьбы, которую можно определить как соперничество эстетических систем, претендовавших на право быть первыми в литературе, быть модернистами.

Но поэзия рубежа веков представляет собой не только последовательную смену литературных течений, развивавшихся в рамках модернизма, она дала русской литературе плеяду новых имен. В русской поэзии эпохи модернизма появилась и в полную меру заявила о себе женская поэзия. На что указывал уже М. Волошин, когда в статье «Женская поэзия» писал: «В то время как творческий дух поэзии как бы отхлынул в том поколении, которое пришло после символистов, целая плеяда женщин-поэтов с ярко вы- 
раженными индивидуальностями вступила в литературу. Эта женская поэзия отличается и разнообразием содержания, и сильно выказанным темпераментом, и четкой искренностью» $[5,118]$.

Каролина Павлова и Зинаида Гиппиус, Поликсена Соловьева и Любовь Столица, София Парнок и Черубина де Габриак, Мирра Лохвицкая и Аделаида Герцык, Марина Цветаева и Анна Ахматова - эти и другие поэтессы заставили современников заявить о феномене женской поэзии.

«Культура Серебряного века, - как пишет Д. Бургин, - поощряла так называемый женский элемент в поэзии (разумеется, в том смысле, как его понимали мужчины) и в то же время скептически и с насмешкой относилась к большинству женщин-поэтов. Потому и неудивительно, что серьезные и талантливые русские поэты-женщины той эпохи вообще отказывались от мысли быть «поэтессами» и хотели, чтобы их воспринимали в первую очередь как поэтов и в последнюю - как женщин-поэтов, если уж этого нельзя избежать. В своем желании быть прежде всего поэтом, без каких бы то ни было уступок или претензий, предъявляемых ее полу...» [3, $10]$.

Феномен женской поэзии (творчества) вызывал и сейчас вызывает разноголосицу суждений и критических замечаний тем более, что на сегодняшний день в литературоведении укрепляется и получает широкое развитие гендерное направление, в русле которого утверждается существование специфики женского литературного творчества и исследуются проявления гендерного компонента на различных уровнях существования и функционирования литературы. Среди литературоведов, активно занимающихся гендерными проблемами в литературе, назовем В. Агееву, Т. Гундророву, Н. Зборовскую М. Михайлову, В. Погребную, М. Рюткенен, И. Савкину, Е. Строганову, А. Улюру, С. Филоненко.

Академическое литературоведение традиционно из всего потока женской поэзии рубежа веков выделяет лишь несколько имен: А. Ахматову, М. Цветаеву, 3. Гиппиус. Остальные поэтессы (а только в антологии «Женской поэзии серебряного века», изданной в 2002 г. названо 101 имя) остались вне внимания литературоведения, представляя собой лишь литературный фон эпохи. Имена Мирры Лохвицкой и Софии Парнок также оказались скрытыми в тени великих поэтесс двадцатого столетия, однако еще в начале века их поэзия считалась выдающимся явлением женской лирики, а критики единодушно присваивали молодым поэтессам титул «русской Сапфо». С легендарной гречанкой Мирру Лохвицкую и Софию Парнок сближала, прежде всего, общая тема их лирического творчества - любовь.

На исходе XIX века «чистая лирика» не пользовалась особой благосклонностью у демократической критики. Представители демократического лагеря (П. Якубович, Е. Соловьев-Андреевич, Ф. Маковский) не принимали ее по идейным соображениям, т. к. этой поэзии была чужда социальная проблематика. Модернистская критика (А. Волынский, К. Бальмонт, 
Вяч. Иванов, Н. Абрамович, Н. Поярков и др.) была более благосклонна, т. к. в произведениях «женской лирики» увидели проявление эротического элемента. И хотя мнение читательской аудитории было совершенно иным, стихами М. Лохвицкой и С. Парнок восхищались, критические оценки неблагоприятно сказались на определении места этих поэтесс в литературном процессе конца XIX - начала XX века.

В последние годы литературоведением предпринимаются попытки исследования творчества М. Лохвицкой и С. Парнок. В 1994 г. впервые за послереволюционный период был издан небольшой отдельный сборник стихотворений М. Лохвицкой и лишь в 1998 г. - С. Парнок. До выхода сборников о творчестве этих поэтесс помнили далеко не все. А имена Лохвицкой и Парнок, наряду с именами других русских поэтесс (Надежда Львова, Лидия Лесная, Паллада Богданова-Бельская, Анна Радлова, Аделаида Герцык, Мария Моравская) «всплывали не сами по себе, а по поводу, в связи с другим, магнетически привлекательным» (С. В. Полякова). Жизнь М. Лохвицкой и ее образ сузились до размера эпизода в судьбе К. Бальмонта, а жизнь и образ 3. Парнок - в судьбе М. Цветаевой.

Отношение критики к творчеству Мирры Лохвицкой не было однородным. Николай Минский отметил, что Мирра Лохвицкая занимает «какое-то серединное место между старою и новою школою». Ее стихи ценили и такие традиционалисты, как Аполлон Майков, Арсений ГоленищевКутузов, Константин Случевский, и такие искатели новизны, как Константин Фофанов, Федор Сологуб, Константин Бальмонт. Но ее же жестко критиковали за свободу чувств, которую она проповедовала в своих стихах. Эти критики обвиняли Мирру в безнравственности и «тяготении к декадентской похоти».

Ее считали безнравственной, а она с удивлением спрашивала:

Я не знаю, зачем упрекают меня,

Что в созданьях моих слишком много огня, Что стремлюсь я навстречу живому лучу

И наветам унынья внимать не хочу.

Что блещу я царицей в нарядных стихах, С диадемой на пышных моих волосах, Что из рифм я себе ожерелье плету, Что пою я любовь, что пою красоту.

Но бессмертья я смертью своей не куплю, И для песен я звонкие песни люблю. И безумью ничтожных мечтаний моих Не изменит мой жгучий, мой женственный стих. 
В сонетах Лохвицкой любовь и красота занимают центральное место, но они отходят от строгих канонов. Некоторые критики видели в них «измельчание поэзии» и гражданского духа.

В стихах лирическая героиня проявляется как страстная, жаркая натура, в то время как в жизни Мирра Лохвицкая была более заземленной, хотя и одевалась порой вычурно, видимо, отдавая дань тогдашней петербургской моде и стилю декаданса. В этом реальном размеренном мире спокойно и уютно женщине - Марии Жибер, но душа поэтессы Мирры Лохвицкой стремится к чему-то не изведанному, яркому и бесконечному. Творчество и жизнь Мирры Лохвицкой - это балансирование между высоким и низким, между прозаическим бытом и романтикой чувств. Дети, муж - все это было, конечно, хорошо, твердо, основательно, но ее тонкая душа требовала чего-то другого. О несовпадении ее житейского облика и образа лирической героини - «вакханки» - писал И. Бунин: «... большая домоседка, по-восточному ленива» [Цит. по 1, 14].

Бурный любовный роман Мирры Лохвицкой с Константином Бальмонтом получил в свое время скандальную огласку, поскольку они даже не пытались скрыть свои чувства, открыто посвящая друг другу стихотворные любовные послания. Мирра Лохвицкая писала:

Я люблю тебя, как море любит солнечный восход, Как нарцисс, к волне склоненный, - блеск и холод сонных вод. Я люблю тебя, как звезды любят месяц золотой, Как поэт - свое созданье, вознесенное мечтой.

Я люблю тебя, как пламя - однодневки-мотыльки, От любви изнемогая, изнывая от тоски. Я люблю тебя, как любит звонкий ветер камыши, Я люблю тебя всей волей, всеми струнами души.

Я люблю тебя, как любят неразгаданные сны:

Больше солнца, больше счастья, больше жизни и весны.

Бальмонт посвятил ей лучший свой сборник «Будем как солнце» (1903): «Художнице вакхических видений, русской Сафо, знающей тайну колдовства».

Мирра Лохвицкая первой переступила «табу», наложенное на пределы женской исповедальности. А. Л. Волынский назвал М. Лохвицкую «особенным стихотворцем» современной поэзии. Он объяснял ее отличие от других поэтов тем, что «она одна откровенно поет любовь». Точнее будет сказать, что «особенность», ясно ощущаемая на рубеже веков и потускневшая уже в 1910-е гг. - появление в ее поэзии новой лирической героини - Женщины. Ее любимые героини - женщины, не тронутые эманси- 
пацией. Если Лохвицкая что-то и отстаивает, то лишь именно это право женщины оставаться женщиной - даже со всеми присущими ей недостатками. На первое место в ценностной шкале она выдвигает сферу чувства, в том числе интимного; для ее лирической героини характерно повышенное внимание к своей внешности; ей свойственна чисто женская любовь к переодеваниям, перевоплощениям.

Одной из особенностей поэзии Лохвицкой является то, что в лирической героине почти всегда узнается автор. Любовь, воспеваемая ею, - это не только эротические переживания и мечтания. С годами в ее творчестве усиливаются мотивы любви, преодолевающей все испытания и побеждающей зло. Лирическая героиня Лохвицкой не пытается «угнаться» за мужчиной в интеллектуальном развитии - у нее свой путь: путь интуиции и инстинктивной мудрости любящего сердца.

Лохвицкая понимает духовный смысл материнства. Она никогда не философствует под маской своих героинь, - тем не менее, жажда познания в ней не менее сильна, чем жажда любви и счастья, но ее орудие - не столько рассудок, сколько интуиция. Религиозность - пожалуй, самая существенная особенность мировоззрения Лохвицкой. Лохвицкая, чьим жизненным выбором было служение семье и воспитание детей, вопреки свойственному ей как творческому человеку стремлению к личной независимости. Борьба с собой, обусловленная христианским мировоззрением, составляет основное содержание ее лирики.

Она была первой русской поэтессой, которая стала писать о любви с откровенностью, прежде позволявшейся лишь мужчинам, - многих это шокировало. Поэтическое творчество М. Лохвицкой характеризуется повышенной эмоциональностью, вдохновленной единственным чувством любви. Ее жизненный опыт любви-испытания определил тематику произведений и явился «откровением» для современников. С другой стороны, М. Лохвицкая сумела отделить в своем творчестве воображаемый мир любовных переживаний от реалий действительной жизни. Однако читающая публика не была готова к разъединению биографического автора и лирической героини, что, возможно, и послужило причиной личной драмы поэтессы. В целом поэзия М. Лохвицкой отражает жизненный опыт возвышенной любви женщины и мужчины.

Муза С. Парнок иная, отличная от музы М. Лохвицкой. Парнок открывает «женский мир» через эстетизацию телесного. Мотивы лесбийской любви открывали поэтессе путь к самоидентификации, к осознанию своей женственности через любовь к другой женщине. Эта тема «пришла» к Парнок вместе с увлечением античностью.

«Мир античных стихов Парнок - это обретенный идеал красоты и гармонии, «музыки в жилах». Поэту незачем прибегать к стилизации: его органика изначально соответствует античному космосу; античный цикл Парнок - это поэзия воспоминания», - пишет Т. Брицкая [2]. 
Древнее детство свое эолийское припоминая, Дева в задумчивый час перебирала струну.

Ветром из-за моря к ней доструилось дыханье Эллады, Ветер, неявный другим, сердце ее шевелит:

Чудится деве - она домечтает мечты твои, Сафо, Недозвучавшие к нам песни твои допоет.

Античность, по мнению исследователей, определяет дальнейшую приверженность поэта классической форме, значимость для него классического наследия.

Софья Яковлевна очень рано осознала свою странную странность, отличие от обычных людей. «Я никогда, к сожалению, не была влюблена в мужчину», - писала она М. Ф. Гнесину $[11,15]$. Эта особенность личной жизни Софии Яковлевны была известна в литературной среде и не скрывалась ею самой. Любовь к женщине - тема множества стихотворений Парнок.

Ее притягивали и привлекали женщины. Ирина Ветринская, исследующая проблему «женской» любви довольно давно и посвятившая этому немало статей и книг, пишет следующее: «Психиатрия классифицирует это как невроз, но я придерживаюсь совершенно противоположного мнения: лесбиянка - это женщина с необычайно развитым чувством собственного «я». Ее партнерша - это ее собственный зеркальный образ; тем, что она делает в постели, она говорит: «Это я, а я - это она. Это и есть высшая степень любви женщины к самой себе»»» $[4,326]$. Мнение спорное, быть может, но не лишенное оснований, и объясняющее многое в этом странном и загадочном явлении - «женской» любви.

Эта тема, табуированная в искусстве, пронизывает все творчество С. Парнок. Но интересны здесь не столько адресаты стихотворений поэтессы, либо факты ее личной жизни, а тот художественный мир, который она создает. Мир полный страсти, любви-греха, страдания и мук, боли и утешения. Ее лирика - это «в своем роде дневник, с редкостной свободой самовыражения запечатлевший историю трудной любви и сложных состояний духа... Здесь с толстовской безоглядной правдивостью описывается любовь женщин» (С. В. Полякова).

С точки зрения С. В. Поляковой, основной пафос творчества С. Парнок составляет «дух жизненной достоверности». Страсть ее не была беспроблемной и в себе убежденной. Чувство отреченности вновь и вновь возвращалось в стихах в стремлении понять самое себя. Это самосознание выражалось не только в дневниковой искренности, оно преломлялось в культурно-исторической символике, искало религиозный смысл своих конфликтов и путь к преображению.

Роман Парнок с Мариной Цветаевой был бурным и страстным, он захватил сразу обеих. Е. Калло пишет: «По силе взаимного проникновения в 
души друг друга - а прежде всего это был роман душ, это было похоже на ослепительную солнечную вспышку» $[7,10]$.

Задаваясь вопросом, что искала в таком необычном чувстве Марина, тогда еще не бывшая столь известной поэтессой, литературоведы приходят к выводу о необычности стремлений самой М. Цветаевой, которая, «будучи по натуре страстной и властной, подобно тигрице, не могла до конца удовлетвориться только ролью замужней женщины и матери. Ей нужна была созвучная душа, над которой она могла бы властвовать безраздельно - гласно ли, негласно, открыто ли, скрыто ли - неважно!» [6].

Не вдаваясь подробно в изложение перипетий любовного романа между С. Парнок и М. Цветаевой, лишь отметим, что влияние Марины Цветаевой на Софью Парнок как личность и Поэта было настолько всеобъемлющим, что, сравнивая строки их стихотворных циклов, написанных почти одновременно, можно найти общие мотивы, похожие рифмы, строки и темы. Власть была неограниченна и велика, в связи с чем исследователи подчеркивают следующее: «Софья Парнок, как Поэт лирический, достигла в этих своих стихотворениях, посвященных ее мучительному чувству к Марине и разрыву с ней, таких высот, которые ставят ее на равных с такими личностями в Поэзии, как Мирра Лохвицкая, Каролина Павлова или даже Анна Андреевна Ахматова» $[11,20]$.

Вот одно из стихотворений, написанных Софьей Парнок в 1915 году, в разгар романа, в «коктебельское лето», когда к их мучительным отношениям прибавилась жгучесть чувства Максимилиана Волошина к Марине - чувства внезапного и довольно сложного:

Причуды мыслей вероломных

Не смог дух алчный превозмочь, -

И вот, из тысячи наемных,

Тобой дарована мне ночь.

Тебя учило безразличье

Лихому мастерству любви.

Но вдруг, привычные к добыче,

Объятья дрогнули твои.

Безумен взгляд, тоской задетый,

Угрюм, ревниво сжатый рот, -

Меня, терзая, мстишь судьбе ты

За опоздалый мой приход.

Своеобразным памятником оборвавшейся любви со стороны Софьи была книга «Стихотворения», вышедшая в 1916 году и сразу запомнившаяся читателям, прежде всего тем, что говорила Софья Яковлевна о своем чувстве открыто, без умолчания, полунамеков, шифровки. 
Снова на профиль гляжу я твой крутолобый

И печально дивлюсь странно-близким чертам твоим.

Свершилося то, чего не быть не могло бы:

На пути на одном нам не было места двоим.

O, этих пальцев тупых и коротких сила,

И под бровью прямой этот дико-недвижный глаз!

Раскаяния, - скажи, - слеза оросила.

Оросила ль его, затуманила ли хоть раз?

Не оттого ли вражда была в нас взаимной

И страстнее любви и правдивей любви стократ.

Что мы двойника друг в друге нашли? Скажи мне,

Не себя ли казня, казнила тебя я, мой брат?

«Снова на профиль гляжу я твой крутолобый..."

Она первая в русской поэзии воспевала сапфическую любовь. Ее лирическая героиня - женщина, свободно и откровенно выражающая свои чувства, живущая миром собственной души. Ее стихи передают ход раздумий на протяжении всей жизни, историю ее любви и духовного роста.

Творчество «русской Сапфо» не вписывалось ни в эстетические нормы дореволюционной литературы, ни в рамки коммунистической морали. И, несмотря на то, что вклад С. Парнок в русскую поэзию XX века был поистине единственным в своем роде, ее имя долгое время было неизвестно широкой публике и практически всеми забыто. И до настоящего времени наиболее известным фактом ее биографии остаются отношения с Мариной Цветаевой в 1914-16 гг. Поэтическое творчество С. Парнок тематически очень разнообразно. Ее литературная деятельность не ограничивалась стихотворством, а жизненный опыт (лесбийские отношения) открыл в русской литературе новую, ранее табуированную тему.

Женская поэзия серебряного века не была однородной, что определяется как культурными условиями «вхождения» женщин-поэтесс в литературу, так и условиями их личной жизни. Творческое наследие двух поэтесс подтверждает тезис гендерного литературоведения о своеобразии художественной самоидентификации авторов-женщин, который необходимо учитывать для полноты литературоведческого анализа произведения. Мирра Лохвицкая и София Парнок - серьезные поэты, заслуживающие внимания и дальнейшего изучения. Им по праву принадлежит достойное место в истории русской литературы - как первым поэтессам, устами которых русская женщина заговорила свободно о своей любви, как авторам, чье творчество за столетие нисколько не утратило тематического интереса и эстетической ценности.

Поэзия «русских Сапфо», не получившая должной оценки у современников и в силу различных причин надолго забытая, нисколько не устарела в наши дни, - напротив, время высвечивает в ней новые грани эстетического своеобразия и совершенства. 


\section{Список использованной литературы}

1. Богомолов Н. А. Критика русского символизма. - М.: Олимп, 2002. - 200 с.

2. Брицкая Т. Пушкинский мир в творчестве Софии Парнок // http://www. silverage. ru/stat/parnok pushkin. htm

3. Бургин Д. София Парнок. Жизнь и творчество русской Сафо. Перевод с английского С. Сивак. - СПб.: Инапресс, 1999. - 513 с.

4. Ветринская И. Послесловие // Женщины, которые любили... женщин. - М.: ОЛМА-ПРЕСС. - 2002. - С. 324-341.

5. Волошин М. Женская поэзия // Волошин М. Стихотворения. Статьи. Воспоминания современников. - М.: Правда, 1991. - С. 117-123.

6. Доля Н. Любовная любовь - ловушка для души (анализ «Письма к Амазонке» М. Цветаевой // http://elles. wallst. ru/person/? id=13

7. Калло Е. О Софии Парнок // «Sub rosa». Аделаида Герцык. София Парнок. Поликсена Соловьева. Черубина де Габриак / Сост. Т. Н. Жуковская, Е. А. Калло. - М.: Эллис Лак, 1999. - С. 7-15.

8. Кононов Н. Предисловие // Бургин Д. София Парнок. Жизнь и творчество русской Сафо. - СПб.: ИНАПРЕСС. - 1999. - С. 5-25.

9. Парнок С. Собрание стихотворений / Вступительная статья, подготовка текста и примечания С. В. Поляковой. - СПб.: ИНАПРЕСС, 1998. - 540 с.

10. Парнок София. Сверстники. Критические статьи. - М.: Глагол, 1999. - 141 с.

11. «Sub rosa»: Аделаида Герцык, София Парнок, Поликсена Соловьева, Черубина де Габриак / Вступ. статья Е. А. Калло. Сост., коммент. Т. Н. Жуковской, Е. А. Калло. - М.: «Эллис Лак», 1999. - 766 с.

\section{Summary}

The article is devoted to gender problems of literature criticism. It considers lyric works of Russian authoresses of the early $20^{\text {th }}$ century. 